\title{
The Effect of Euglycemic Hyperinsulinemia on Cerebral Cortical Glucose Metabolism in Newborn Beagles ${ }^{1}$
}

\author{
CLEIDE TRINDADE, MARIAN HUANG, SONIA HULMAN, SUSAN REEF, AND \\ ROBERT KLIEGMAN \\ Department of Pediatrics, Case Western Reserve University Rainbow Babies and Childrens Hospital, Cleveland, \\ Ohio 44106 and Department of Pediatrics, Faculdade de Medicina de Botucatu, UNESP, Sao Paulo, Brazil
}

\begin{abstract}
There is a paucity of information on the significance of insulin on neonatal cerebral glucose metabolism. The effect of insulin on neonatal cerebral glucose uptake and cerebral cortical metabolic intermediates was investigated with the euglycemic hyperinsulinemic clamp in unanesthetized beagles during the first day of life. Insulin was infused at various rates to sustain an elevated steady state plasma insulin concentration in individual pups. Furthermore, blood glucose and 2-deoxyglucose levels were also maintained ("clamped") in a steady state by infusion of glucose and 2-deoxy- $\left[{ }^{14} \mathrm{C}\right]$-glucose. Mean ( \pm SD) plasma insulin levels were $20 \pm 12$ and $2971 \pm 3386(33-14330)$ $\mu \mathrm{U} / \mathrm{ml}$ in control and hyperinsulinemic pups. Blood glucose concentration was $4.43 \pm 2.64 \mathrm{mM}$ during basal periods and $4.54 \pm 2.87 \mathrm{mM}$ during the clamp period in study pups. Basal fasting glucose utilization in study pups was $43.9 \pm 24 \mu \mathrm{mol} / \mathrm{kg} / \mathrm{min}$ and increased to $60.9 \pm 35.2 \mu \mathrm{mol} /$ $\mathrm{kg} / \mathrm{min}(p<0.001)$ during hyperinsulinemia. Immediately after the euglycemic hyperinsulinemic clamp or fasting in control pups, the cerebral cortex was frozen to the temperature of liquid nitrogen. No differences were noted for any cerebral cortical intermediate between the two pup groups. In addition, there was no relationship between the cerebral intermediates concentration when analyzed as a function of plasma insulin levels. The uptake of cerebral 2-deoxyglucose was analyzed as a function of plasma insulin concentration (120-6900 $\mu \mathrm{U} / \mathrm{ml})$. Brain tissue demonstrated a positive linear relationship for 2-deoxyglucose uptake as a function of plasma insulin concentration. Although static determination of brain metabolites were not influenced by hyperinsulinemia, there was a positive effect of insulin on cerebral glucose uptake. Either directly or indirectly, insulin may increase brain glucose utilization in the newborn dog. (Pediatr Res 23: 474-479, 1988)
\end{abstract}

\section{Abbreviations}

2-DG, 2-deoxy-[ $\left[{ }^{14} \mathrm{C}\right]$-glucose UDP-glucose, uridine diphosphoglucose glucose-6-P, glucose-6-phosphate fructose-6-P, fructose-6-phosphate HI, hyperinsulinemic clamp

Received October 19, 1987; accepted January 6, 1988.

Correspondence and requests for reprints R. Kliegman, M.D., Department of Pediatrics, Rainbow Babies and Childrens Hospital, 2101 Adelbert Road, Cleveland, OH 44106.

Supported by NIH Grant HD 20851.

${ }^{1}$ Presented in part at the Society for Pediatric Research Meeting, Anaheim, California, April 1987.
Glucose is considered the major substrate for brain energy metabolism. While it is know that insulin affects glucose uptake and metabolism in peripheral tissues, it is a matter of speculation whether insulin affects the uptake and utilization of glucose by the brain. Presently the results of studies that have investigated the effects of insulin on brain glucose uptake are inconclusive (1-8). Although the central nervous system is not considered an insulin sensitive tissue, recent studies have demonstrated high concentrations of insulin in the brain (9), and the presence of insulin receptors in microvessels $(10,11)$ as well as within the brain substance (12-15). Difficulties of interpretation of the present data may be related to the use of in vitro techniques and in vivo investigations that do not have a steady state of blood glucose or insulin levels.

Investigations on the effects of insulin on the developing nervous system suggest that insulin may have an action on cerebral macromolecule synthesis $(16,17)$. In the developing brain, insulin stimulates protein, and RNA and DNA synthesis in vitro $(16,17)$.

Although insulin may have difficulty traversing the mature blood brain barrier, insulin has been demonstrated to enter the brain in the adult in the region of the circumventricular area (18). This location is thought to be devoid of a blood brain barrier. Immature mammals have a more permeable blood brain barrier (19) which may result in greater passage of circulating insulin into the developing central nervous system. Presently there is a paucity of information on the effects of insulin on the immature mammalian brain. Herein we analyzed the effect of insulin on glucose utilization in the brain of newborn beagles by using the euglycemic hyperinsulinemic clamp and the simultaneous infusion of 2-deoxy- $\left[{ }^{14} \mathrm{C}\right]$-glucose. A subsequent report will discuss the detailed results of liver and muscle metabolism from these pups.

\section{MATERIALS AND METHODS}

Materials. D- $\left[6-{ }^{3} \mathrm{H}\right]$ glucose and 2-deoxy- $\left[{ }^{14} \mathrm{C}\right]$-glucose were purchased from New England Nuclear, Boston, MA. All enzymes were purchased from Sigma Chemical Co., St. Louis, MO. All chemicals and standards were reagent grade.

Animals. Pregnant beagle dogs were maintained in kennels and fed standard canine diet until 1-3 days before delivery when they were fasted but had free access to water. Cesarean sections were performed at term after intravenous anesthesia with chlorpromazine $(4 \mathrm{mg} / \mathrm{kg})$ and $1 \%$ lidocaine infiltrated in the incision area. After delivery newborn pups were dried and maintained in incubators at $37^{\circ} \mathrm{C}$. After stabilization, umbilical arterial and venous catheters were placed without trauma or stress and the pups rested in incubators during the remainder of the study (20). 
The tip of the venous catheter was positioned in the inferior vena cava. This protocol was approved by the Case Western Reserve University Animal Welfare Committee.

Euglycemic hyperinsulinemic clamp. This technique was used to assess the effects of hyperinsulinemia without the effects of hypoglycemia. Fifty-one euglycemic hyperinsulinemic pups were studied. To determine glucose turnover and glucose utilization during the clamp, tracer quantities of $\left[6-{ }^{3} \mathrm{H}\right]$ glucose $(4.5 \mu \mathrm{Ci} / \mathrm{kg} /$ $\mathrm{h}$; specific activity, $33.9 \mathrm{Ci} / \mathrm{mmol}$ ) were infused at a constant rate during the entire study which lasted $195 \mathrm{~min}$ after a priming dose. This infusion was begun between $3-6 \mathrm{~h}$ of life in previously fasted pups. After $60 \mathrm{~min}$ a steady state of tracer radioactivity was achieved and the blood glucose concentration at 90 min was considered the basal level for the clamp study. The euglycemic HI was performed as described by DeFronzo et al. (21) and initiated at $90 \mathrm{~min}$ of the study. Within the context of this clamp, blood glucose and plasma insulin levels are "clamped" constant. Any requirement of exogenous glucose to maintain normal levels of blood glucose during the clamp is a direct reflection of insulin stimulated tissue glucose uptake. Only insulin-sensitive tissue will respond in this system. Pork insulin $(100 \mathrm{U} / \mathrm{ml})$ was diluted in normal saline and was infused at a constant rate of either $3.75,7.5,15,30,60$, or $100 \mathrm{mU} / \mathrm{kg} / \mathrm{min}$ via the umbilical vein during the subsequent $105 \mathrm{~min}$ of the study. In order to maintain euglycemia, blood glucose was determined at each 10- to $15-\mathrm{min}$ interval from arterial blood on a Beckman glucose analyzer and an exogenous infusion of glucose was adjusted using the negative feedback principle (21). Blood samples were also collected at 75 , 90 , and $105 \mathrm{~min}$ after the beginning of the insulin clamp, when the steady state for the clamp period was reached, to determine plasma insulin concentration and glucose kinetic data. All blood withdrawn was replaced by normal saline solution.

In 20 newborn beagle dogs 2 -deoxy-[ $\left[{ }^{14} \mathrm{C}\right]$-glucose was added to the clamp infusate to study in vivo glucose uptake by the brain in the presence of euglycemia and varying grades of hyperinsulinemia $(22,23)$. $\left[{ }^{14} \mathrm{C}\right]-2-\mathrm{DG}$ (specific activity $282.0 \mathrm{mCi} / \mathrm{mmol}$ ) was infused at a constant rate of $(0.1 \mu \mathrm{Ci} / \mathrm{kg} / \mathrm{min})$ during the clamp study. Insulin infusion rates were $3.75,15,30$, or $60 \mathrm{mU} /$ $\mathrm{kg} / \mathrm{min}$.

Immediately at the end of the clamp studies, the pups were killed by a double guillotine. Samples of cerebral cortex, liver, and muscle from the hindquarter were collected and freezeclamped in less than $3 \mathrm{~s}$, placed in liquid $\mathrm{N}_{2}$, and later stored at $-80^{\circ} \mathrm{C}$ until further analyses of tissue glycolytic intermediates and 2-DG radioactivity. Control pups $(n=14)$ did not receive insulin but did have fasting levels of glucose turnover quantitated with tracer glucose and cerebral cortical tissue intermediates analyzed as described above.

Analyses. The homogenization and extraction of cerebral cortex, liver, and muscle were performed as reported previously (20). Glucose, glycogen, UDP-glucose, glucose-6-P, fructose-6-P, phosphoenolpyruvate, pyruvate, lactate, citrate, $\alpha$-ketoglutarate, ATP, alanine, glutamine, and glutamate were assayed as reported previously (20). Plasma insulin was determined by radioimmunoassay on aliquots collected before and during the clamp period. $\left[6-{ }^{3} \mathrm{H}\right]$ glucose and 2-deoxy- $\left[{ }^{14} \mathrm{C}\right]$-glucose, after extraction and neutralization, were separated from other compounds by ion exchange chromatography in analytical grade cation exchange resin AG $50 \mathrm{~W}-\mathrm{X} 8$ and analytical grade anion exchange resin AG 1-X8 (Bio-Rad Laboratories, Richmond, $\mathrm{CA}$ ) and counted in the commercial fluid, Scinti-Verse II (Fisher Scientific Co., Pittsburgh, PA). The measurement of the radioactivity of 2DG in blood and tissues was done in a Beckman LS7500 liquid scintillation system. The counts were expressed as disintegrations per mass unit per min with time being the duration of the infusion. Because of variations of the infusate quantities of 2DG and corresponding variability of blood 2-DG values, blood and tissue counts were corrected to a standardized level of circulating radioactivity. This correction made it possible to compare the tissue levels between pups with different blood 2-
DG concentrations, now assuming a uniform concentration of 2-deoxy- $\left[{ }^{14} \mathrm{C}\right]$-glucose in the blood. We also analyzed the uptake of 2-DG by the tissues by the ratio $\mathrm{Cm} / \mathrm{C}_{\mathrm{b}}$. $\mathrm{Cm}$ is the counts found in tissue from 2-DG per unit of mass $(\mathrm{dpm} / \mathrm{g})$ and $\mathrm{C}_{\mathrm{b}}$ is the level of 2-deoxy- $\left[{ }^{14} \mathrm{C}\right]$-glucose per $\mathrm{ml}$ of blood $(\mathrm{dpm} / \mathrm{ml})$. This method of calculation needs no correction factor because tissue uptake is related to blood levels of 2-DG.

Statistical analysis. Student's $t$ test was used to compare means between control and euglycemic hyperinsulinemic pups for brain glucose, its metabolites, and amino acids. Analysis of variance was included to determine analyses of brain metabolites. Paired $t$ test was used for comparison of counts from 2-DG among brain, liver, and muscle in the same animal. Significant values were considered for $p<0.05$. Regression analysis was used for the analyses of plasma insulin and the levels of counts from 2$\mathrm{DG}$ in tissue and for the ratio $\mathrm{Cm} / \mathrm{C}_{\mathrm{b}}$. Results are mean $\pm \mathrm{SD}$. Data presented herein will concentrate on brain metabolism.

\section{RESULTS}

Circulating kinetic data. Brain glucose, glycolytic, and Krebs cycle and related metabolites were assayed in 14 control and 31 euglycemic hyperinsulinemic newborn dogs. 2-DG uptake by brain was determined in an additional 20 euglycemic hyperinsulinemic pups. The weight of the pups was $0.272 \pm 0.030 \mathrm{~kg}$ for controls and $0.259 \pm 0.039 \mathrm{~kg}$ for hyperinsulinemic pups. Basal glucose concentrations for control pups were $3.4 \pm 1.4$ and $4.4 \pm 2.6 \mathrm{mM}$ in pups before hyperinsulinemia. During the clamp in the steady state, blood glucose was $4.5 \pm 2.8 \mathrm{mM}$. The differences between glucose levels were not significant. The plasma insulin in the fasted control group was $20 \pm 12 \mu \mathrm{U} / \mathrm{ml}$, fasting basal insulin $17 \pm 15 \mu \mathrm{U} / \mathrm{ml}$, and during hyperinsulinemia the plasma insulin level was $2971 \pm 3386 \mu \mathrm{U} / \mathrm{ml}$ (range 3314,330 ). In the steady state (defined as glucose specific activity variance less than $10 \%$ ), glucose turnover for controls was 33.2 $\pm 7.8 \mu \mathrm{mol} / \mathrm{kg} / \mathrm{min}$ and was not significantly different from glucose turnover for study pups before insulin administration $(43.9 \pm 24 \mu \mathrm{mol} / \mathrm{kg} / \mathrm{min})$. During the clamp period blood glucose levels did not change; however, insulin enhanced systemic glucose utilization $(60.9 \pm 35.2 \mu \mathrm{mol} / \mathrm{kg} / \mathrm{min}) 1.4$ times above basal fasting levels $(p<0.001)$. In the steady state, during the clamp period, the levels of blood glucose, 2-DG, and plasma insulin were held constant (Fig. 1).

Brain intermediate metabolism. The results of the cerebral cortical glucose, glycogen, UDP-glucose, and ATP are seen in Table 1 . There were no significant differences between the means for these intermediates. The cerebral glycolytic intermediates: glucose-6-P, fructose-6-P, phosphoenolpyruvate, pyruvate, and

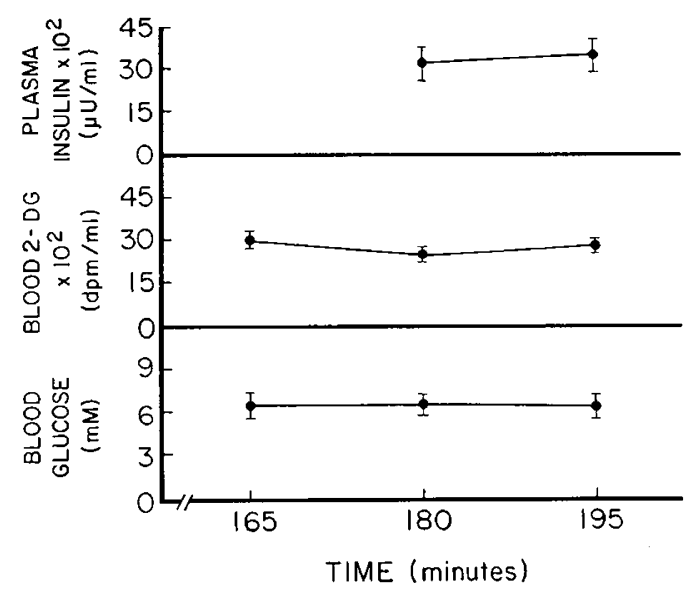

Fig. 1. Steady state blood glucose, blood 2-DG, and plasma insulin levels in euglycemic hyperinsulinemic dogs used for the determination of 2-DG uptake by brain. Values are mean \pm SEM. 
lactate were not significantly different between control and hyperinsulinemic pups (Table 2). The intermediates of the Krebs cycle, citrate and $\alpha$-ketoglutarate, were also not significantly different between the two groups (Table 2). Furthermore, the concentrations of brain amino acids: alanine, glutamate, and glutamine were not different in controls and HI pups (Table 3). When any of these metabolites were analyzed as a linear regression fashion there were no significant correlations between metabolite levels as a function of the plasma insulin concentration during hyperinsulinemia.

The uptake of 2-DG by the brain was analyzed as a function

Table 1. Cerebral cortical glucose and related intermediates in control and euglycemic HI newborn pups (mean $\pm S D)^{*}$

\begin{tabular}{ccc}
\hline & Control pups & HI pups \\
\hline Blood $(\mathrm{mM})$ glucose & $3.12 \pm 1.51(6) \dagger$ & $4.03 \pm 1.85(30)$ \\
Brain $(\mu \mathrm{mol} / \mathrm{g})$ glucose & $1.70 \pm 0.92(14)$ & $2.00 \pm 1.10(29)$ \\
glycogen & $0.92 \pm 0.47(9)$ & $1.12 \pm 0.69(23)$ \\
UDP glucose & $0.067 \pm 0.026(12)$ & $0.069 \pm 0.035(28)$ \\
ATP & $2.021 \pm 1.261(11)$ & $1.414 \pm 0.952(23)$ \\
\hline
\end{tabular}

* No significant difference between control and HI by Student's $t$ test. $\dagger$ Sample size.

Table 2. Cerebral glycolytic and Krebs cycle intermediates in control and euglycemic HI newborn dogs ( $\mu \mathrm{mol} / \mathrm{g})$ (mean \pm $S D)^{*}$

\begin{tabular}{lll}
\hline & \multicolumn{1}{c}{ Control pups } & \multicolumn{1}{c}{ HI pups } \\
\hline Glucose-6-P & $0.066 \pm 0.023(8) \dagger$ & $0.052 \pm 0.024(18)$ \\
Fructose-6-P & $0.016 \pm 0.008(8)$ & $0.016 \pm 0.007(18)$ \\
Phosphoenolpyruvate & $0.055 \pm 0.015(11)$ & $0.058 \pm 0.032(21)$ \\
Pyruvate & $0.115 \pm 0.055(12)$ & $0.123 \pm 0.055(27)$ \\
Lactate & $0.995 \pm 0.530(10)$ & $0.933 \pm 0.415(29)$ \\
Citrate & $0.206 \pm 0.054(9)$ & $0.211 \pm 0.084(27)$ \\
$\alpha$-ketoglutarate & $0.064 \pm 0.034(9)$ & $0.048 \pm 0.030(24)$ \\
\hline
\end{tabular}

* No significant differences between control and HI by Student's $t$ test. $\dagger$ Sample size.

Table 3. Brain amino acids in control and euglycemic HI newborn dogs ( $\mu \mathrm{mol} / \mathrm{g})$ (mean $\pm S D)^{*}$

\begin{tabular}{lcc}
\hline & Control pups & HI pups \\
\hline Alanine & $0.590 \pm 0.317(8) \dagger$ & $0.575 \pm 0.266(14)$ \\
Glutamate & $4.503 \pm 1.457(13)$ & $4.239 \pm 0.722(25)$ \\
Glutamine & $8.634 \pm 1.535(11)$ & $7.788 \pm 1.864(25)$ \\
\hline
\end{tabular}

No significant differences between control and HI by Student's $t$ test. $\dagger$ Sample size.

Table 4. Relation between the uptake of 2-deoxy-[ $\left.{ }^{14} \mathrm{C}\right]$-glucose by tissues and plasma insulin*

\begin{tabular}{|c|c|c|c|}
\hline & $\begin{array}{l}\text { Mean uptake } \\
(\mathrm{dpm} / \mathrm{g} / \mathrm{min})\end{array}$ & $\begin{array}{c}\text { Correlation } \\
r(v s \text { plasma } \\
\text { insulin })\end{array}$ & $p$ \\
\hline Brain & $\begin{array}{c}\dagger 281 \pm 189(70-713) \\
(n=20)\end{array}$ & 0.61 & $<0.01$ \\
\hline Liver & $\begin{array}{c}\$ 514 \pm 381(102-1611) \\
(n=19)\end{array}$ & 0.52 & $<0.05$ \\
\hline Muscle & $\begin{array}{c}\S 245 \pm 151(80-498) \\
(n=19)\end{array}$ & 0.71 & $<0.001$ \\
\hline
\end{tabular}

*Values are mean $\pm \mathrm{SD}$ and correspond to total dpm in a specific tissue divided by the time of the infusion period.

$\dagger, \ddagger, \S$ Comparison among brain, liver and muscle total mean 2-DG uptake by paired $t$ test: $\ddagger>\uparrow, p<0.02 ; \ddagger>\S, p<0.01$ by paired $t$ test. of plasma insulin and also compared with more insulin-sensitive tissues such as liver and muscle. The mean counts of 2-DG recovered in tissue after the 2-DG infusion was: in the cerebral cortex, $281 \pm 189 \mathrm{dpm} / \mathrm{g} / \mathrm{min}$; liver, $514 \pm 381 \mathrm{dpm} / \mathrm{g} / \mathrm{min}$; and muscle, $245 \pm 151 \mathrm{dpm} / \mathrm{g} / \mathrm{min}$ (Table 4$)$. The analysis of the total uptake of 2-DG during the clamp period by tissues showed a higher uptake for liver when compared to cerebral cortex $(p<0.02)$ and muscle $(p<0.01)$ (Table 4$)$. There is no significant difference in $2-D G$ uptake between cerebral cortex and muscle (Table 4). The correlation coefficients for the counts in tissue from 2-DG as a function of the insulin levels in the plasma during the clamp were: brain, $r=0.61, p<0.01$ (Fig. 2); liver, $r=0.52, p<0.05$ (Fig. 3); and muscle, $r=0.71, p<0.001$ (Fig. 3). During the clamp period, we did not identify any correlation between plasma insulin, blood 2-DG, and blood glucose levels.

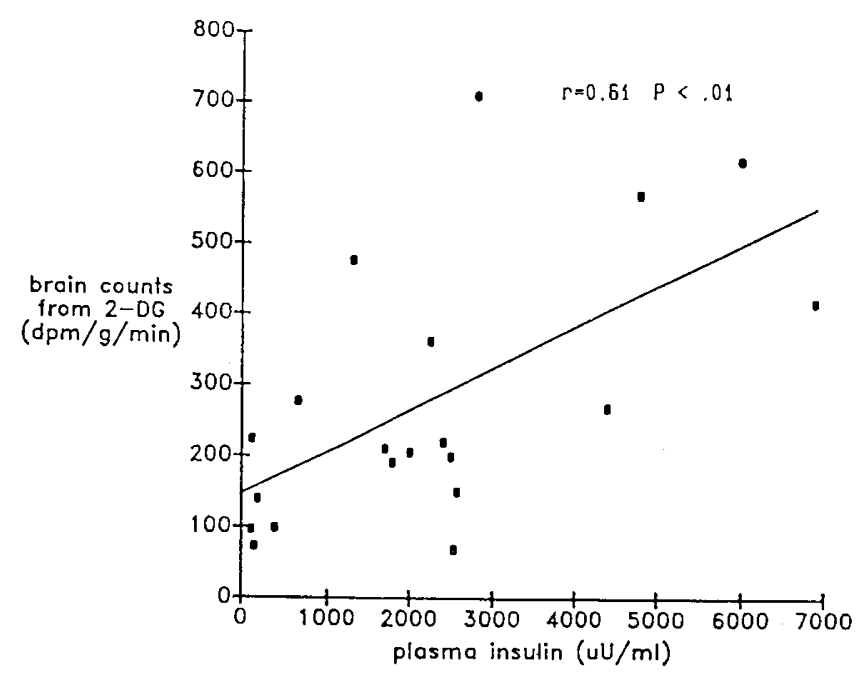

Fig. 2. Relation between plasma insulin levels and counts from 2 DG in brains of newborn beagles submitted to euglycemic hyperinsulinemic clamp with constant infusion of 2 -deoxy- $\left[{ }^{14} \mathrm{C}\right]$-glucose at different, but constant rates of insulin infusion. Regression equation, $y=147+$ $0.058 \mathrm{x}$.

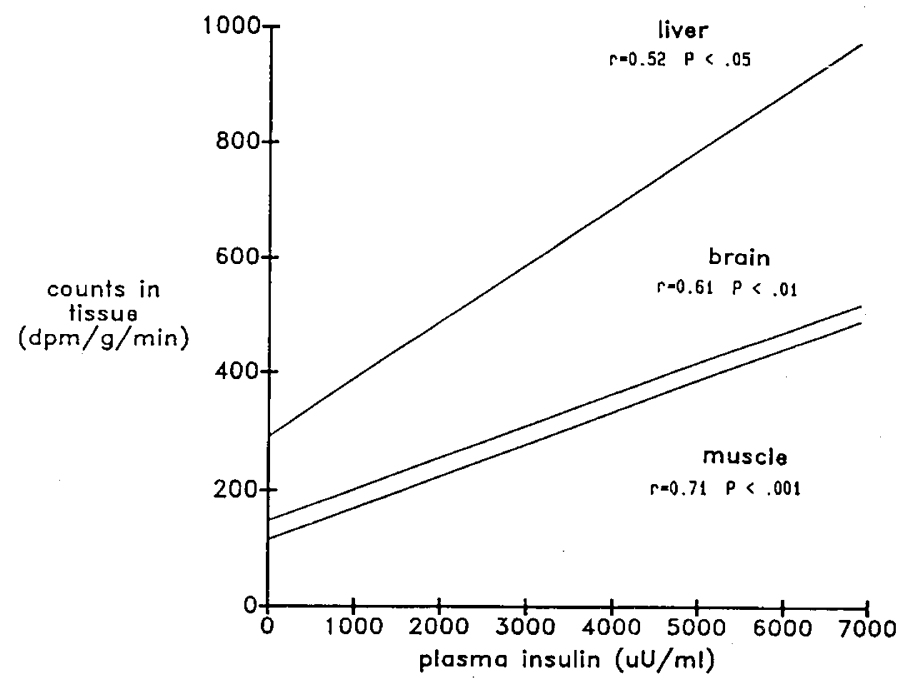

Fig. 3. Regression lines of the relation between counts from 2-DG in brain cortex, liver, and muscle as functions of the plasma insulin level of newborn beagles. The pups were submitted to euglycemic hyperinsulinemic clamp with constant infusion of 2-deoxy- $\left[{ }^{14} \mathrm{C}\right]$-glucose and different rates of insulin infusion. Regression equation for liver, $y=290+$ $0.099 \mathrm{x}$ and for muscle, $y=116+0.054 \mathrm{x}$. 
Table 5. Relation between the mean ratio of activity of $2-D G$ in tissue and in plasma versus the plasma insulin concentration (mean $\pm S D)$

\begin{tabular}{|c|c|c|c|}
\hline & $\begin{array}{c}\text { mean ratio } \\
\mathrm{Cm}^{*} / \mathrm{C}_{\mathrm{b}} \dagger\end{array}$ & $r(v s$ plasma insulin) & $p$ \\
\hline Brain & $\begin{array}{c}\ddagger 2.72 \pm 1.81(7.00-0.70) \\
(n=20)\end{array}$ & 0.56 & $<0.02$ \\
\hline Liver & $\begin{array}{c}\S 5.023 \pm 3.47(14.07-1.02) \\
(n=19)\end{array}$ & 0.51 & $<0.05$ \\
\hline Muscle & $\begin{array}{c}\| 2.49 \pm 1.52(4.98-1.00) \\
(n=19)\end{array}$ & 0.64 & $<0.01$ \\
\hline
\end{tabular}

${ }^{*} \mathrm{Cm}$, tissue accumulation of counts from 2-deoxy- $\left[{ }^{14} \mathrm{C}\right]$-glucose per unit mass (dpm/g).

$\dagger \mathrm{C}_{\mathrm{b}}$, blood 2-deoxy-[ $\left[{ }^{14} \mathrm{C}\right]$-glucose per $\mathrm{ml}(\mathrm{dpm} / \mathrm{ml})$.

$\$, \S$, $\|$ Comparison among brain, liver and muscle mean ratios for range of insulin by paired $t$ test: $\S>\ddagger, p<0.02 ; \S>\|, p<0.05$ by paired $t$ test.

I Sample size.

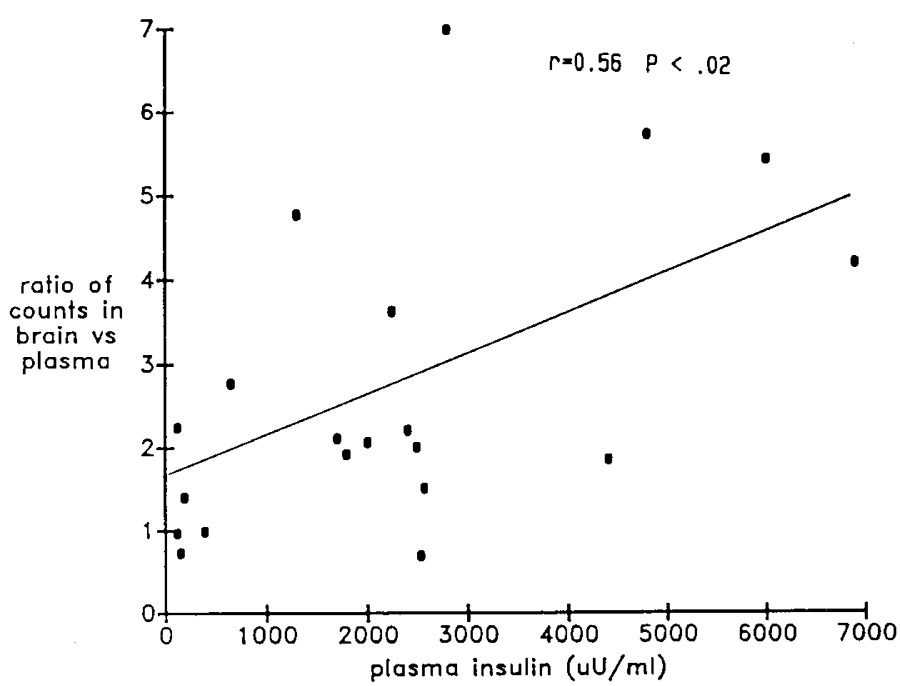

Fig. 4. Relation between the ratio of the activity of 2-DG in brain and 2-DG in blood as a function of the plasma insulin level of newborn beagles submitted to euglycemic hyperinsulinemic clamp with constant infusion of 2-deoxy- $\left[{ }^{14} \mathrm{C}\right]$-glucose and different rates of insulin infusion. Regression equation, $y=1.53+0.005 \mathrm{x}$.

The ratio between the counts from 2-DG in the brain, liver, and muscle and the corresponding 2-DG activity in the blood also demonstrated a significant positive correlation with the plasma insulin levels (Table 5). The correlation coefficient for the brain to blood ratio as a function of the simultaneous plasma insulin level was $r=0.56(p<0.02$ ) (Fig. 4); for liver, $r=0.51$ $(p<0.05)$; for muscle, $r=0.64$ ( $p<0.01)$ (Table 5). The comparison among the ratio for total tissue 2-DG radioactivity accumulated during the entire clamp period versus plasma radioactivity values showed a higher mean ratio for liver when compared to brain $(p<0.02)$ and muscle $(p<0.05)$. The mean brain ratio was not significantly different from the mean muscle ratio (Table 5).

The uptake of 2-DG by tissues was also analyzed as a function of the exogenous glucose infusion rate required to maintain euglycemia. There was no relationship between the exogenous glucose infusion rate with brain, $r=0.29$; liver, $r=0.29$; and muscle, $r=0.08$; 2-DG uptake during the clamp period.

\section{DISCUSSION}

In adult species there is uncertainty as to the effects of insulin on cerebral metabolism. Many areas of the brain have insulin receptors $(8,14,15)$. These receptors are specific for insulin and demonstrate standard saturation kinetics $(9,12)$. Furthermore, insulin may gain entry into the brain in areas such as the circumventricular organ where there is no blood brain barrier (18). In addition, insulin levels have been demonstrated to increase in the cerebral spinal fluid in situations of persistent and prolonged circulating hyperinsulinemia in adult dogs (24). Insulin may also bind directly to blood vessel endothelial cells (10, 18) and affect metabolite transport at this level.

Prior investigations have demonstrated an effect of insulin on increasing unidirectional glucose influx into the brain (5). Additional investigations have observed no increased influx, but demonstrated a net increase of glucose gain by the brain (1) and demonstrated that hyperinsulinemia decreased outward hexose transport more than the inward transport resulting in an increase in the hexose distribution space in the brain (25). Furthermore, insulin has also been demonstrated to enhance cerebral tissue protein, RNA, and DNA synthesis $(16,17)$. Insulin may influence glucose uptake by directly affecting the transport mechanism. Alternatively, the increased synthesis of cerebral macromolecules may result in the need for increased uptake of oxidizable fuels or macromolecule precursors. Thus, insulin-stimulated synthesis of cerebral protein may indirectly result in increased cerebral glucose utilization to provide the energy required for tissue synthesis.

The euglycemic hyperinsulinemic clamp is an excellent method for the study of glucose utilization and the effects of insulin on insulin responsive tissue in vivo by maintaining constant circulating hyperinsulinemia in the presence of euglycemia. The amount of infused glucose needed to clamp blood glucose at basal values is directly related to insulin-stimulated glucose utilization. Insulin concentrations range from physiologic to pharmacologic. The latter high range of plasma insulin levels enable the determination of the maximum possible response to insulin. This technique was adapted in our laboratory for the study of glucose utilization in newborn beagles (26). The 2-deoxy-[ $\left.{ }^{14} \mathrm{C}\right]$-glucose method has been used to quantify insulin sensitivity by the cerebral tissue and also to study glucose utilization by the brain (22). 2-DG is transported through the blood brain barrier by the same carrier that transports glucose. By combining the 2-DG method and the hyperinsulinemic clamp, it was possible to study the effects of insulin on the cerebral uptake of glucose as a function of circulating insulin levels under steady state conditions in the newborn beagle.

In the first part of this study, we analyzed intermediates of glucose metabolism in the brain cortex during the clamp when the newborn pups remained euglycemic. A significant increase was noted in total body glucose utilization during the clamp period. These data indicate that glucose utilization was increased only in the tissues that were responsive to the action of insulin. Despite increased total body glucose uptake and high levels of plasma insulin, the concentrations of brain glucose, glycogen, and its intermediate, UDP-glucose, were not affected by insulin. In adult rats subjected to euglycemic hyperinsulinemia there was also no effect of this method on these hepatic intermediates (27). We could not demonstrate an action of insulin on brain glycolytic intermediates. Glucose metabolism was also analyzed by the determination of the cerebral amino acids derived from glycolysis or the Krebs cycle, alanine, glutamate, and glutamine. These were also not affected by hyperinsulinemia.

The observation that cerebral intermediates were not affected by circulating hyperinsulinemia may suggest that insulin has little or no detectable effect on cerebral glucose metabolism. Nonetheless, the assay of cerebral cortical intermediates is a static determination of a potentially dynamic situation, e.g. increased cerebral glucose uptake. Cerebral glucose utilization may be stimulated and flux may increase through glycolysis and the Krebs cycle without discernible perturbations of the intermediates of these pathways. Brain glucose concentration may not increase because of rapid phosphorylation of glucose to glucose6-P. Subsequently enhanced glycolytic flux may maintain cere- 
bral glycolytic intermediate levels if the rate of glucose phosphorylation is equal to the rate of glucose utilization and the rate of acetyl CoA entry into the Krebs cycle. Indeed, except under major perturbation stresses such as severe ischemia, it is unusual to detect alterations of intracellular intermediates, including glucose, during periods of enhanced glycolysis, glycogen synthesis, or glycogenolysis. The metabolite response of the newborn pup was therefore similar to that of the adult rat after euglycemic hyperinsulinemia (27). If basal glucose availability to the brain is sufficient, further enrichment (increased levels) of the concentrations of the glycolytic and Krebs cycle intermediate pools may not be necessary. Further increases of cerebral glucose utilization may have no effect on the static determination of these metabolites.

Determination of insulin-stimulated cerebral glucose uptake with the 2-deoxy glucose method is a more sensitive indicator of cerebral glucose uptake than are analyses of intermediate levels. Because the decreased sensitivity of the biochemical methods could be responsible for the results observed, we analyzed the effect of insulin on glucose utilization as determined by the 2DG method, which is a more dynamic process. A positive correlation between plasma insulin concentration and the amount of 2-DG recovered in the brain was observed within the range of plasma insulin values achieved during the clamp period (120-6900 $\mu \mathrm{U} / \mathrm{ml})$. A similar positive relationship was demonstrated in liver and muscle tissues, which are considered to be sensitive to the action of insulin. The ratio between the counts from 2-DG in the tissues and the 2-DG in the blood also supported the evidence that higher levels of insulin in the plasma may lead to higher levels of extraction of 2-DG from blood. It is also important to consider that although the counts from 2-DG in the tissue may be related to the available substrate in the blood, no relation was evident between the level of blood glucose or the glucose infusion rate or the concentration of the tracer in the blood and the level of plasma insulin. This leads us to conclude that the higher levels of circulating plasma insulin were responsible for the increased 2-DG uptake by brain. According to the principle of the clamp technique, glucose was infused to maintain blood glucose concentrations to prevent hypoglycemia which would be due to insulin-stimulated tissue glucose uptake. Thus any increase of tissue 2-DG reflects insulin stimulated uptake rather than substrate driven uptake.

Variations in cerebral blood flow induced by hyperinsulinemia could potentially increase or decrease the uptake of 2-DG by the brain. Although cerebral blood flow was not determined in this experiment, previous investigations have demonstrated that the cerebral blood flow of newborn dogs does not change in response to hyperinsulinemia (28). It is interesting to note that muscle appears to have the same response to insulin as the brain. This does not mean that newborn brain should be considered as insulin sensitive as muscle tissue has been traditionally considered sensitive. Rather the observed data may suggest that newborn muscle tissue is less sensitive than more mature adult muscle tissue, and therefore demonstrates a similar response to newborn brain. The concept that muscle may be one site responsible for neonatal insulin resistance is the subject of a parallel study (29).

The differences between the experimental model we have used and the models described in the literature also need to be considered. First, we studied the neonatal dog at 3-6 h after birth. At this time of maturation the blood brain barrier has been demonstrated to be more permeable than adult animals (19). Moreover, the presence of the steady state condition for plasma insulin, blood glucose, and the constant infusion rate of 2-DG allows for glucose uptake by both the brain and by traditionally more insulin-sensitive organs. Previous studies using acute 2-DG and insulin boluses may not provide sufficient 2-DG substrate for less sensitive organs, e.g. the brain.

We conclude that insulin acts on the brain of newborn beagles by enhancing glucose uptake. We speculate that the immature canine brain may be an insulin-sensitive tissue and this may be, in part, due to a more permeable blood brain barrier or to the possible action of insulin on macromolecule synthesis $(16,17)$. The intrinsic mechanisms of this action have yet to be determined. Whether the insulin effect occurs at the insulin receptors of the brain microvessels, at the blood brain barrier, or at the receptors localized in the brain cells remains speculative.

Acknowledgments. The authors express appreciation to Ms. Donna Marie Kall and Ms. Kristen Leigh Voelker for technical assistance and to Ms. Carolyn D. Grier, Ms. Sandra Hartman, and Ms. Karen Toil for preparation of the manuscript.

\section{REFERENCES}

1. Daniel PM, Lover ER, Pratt OE 1975 Insulin and the way the brain handles glucose. J Neurochem 25:471-476

2. Ferré P, Leturque A, Burnol A, Penicaud L, Girard J 1985 A method to quantify glucose utilization in vivo in skeletal muscle and white adipose tissue of the anaesthetized rat. J Biochem 228:103-110

3. Goodner CJ, Hom FG, Berrie MA 1980 Investigation of the effect of insulin upon regional brain glucose metabolism in the rat in vivo. Endocrinology 107:1827-1832

4. Grunstein HS, James DE, Storlien LH, Smythe GA, Kraegen EW 1985 Hyperinsulinemia suppresses glucose utilization in specific brain regions: in vivo studies using the euglycemic clamp in the rat. Endocrinology 116:604610

5. Hertz MM, Paulson OB, Barry DI 1981 Insulin increases glucose transfer across the blood brain barrier in man. J Clin Invest 67:597-604

6. Hom FG, Goodner CJ, Berrie MA 1984 A $\left({ }^{3} \mathrm{H}\right) 2$-deoxyglucose method for comparing rates of glucose metabolism and insulin responses among rat tissues in vivo. Validation of the model and the absence of an insulin effect on brain. Diabetes 33:141-152

7. Leturque A, Ferre P, Burnol AF, Kande J, Maulard P, Girard J 1986 Glucose utilization rates and insulin sensitivity in vivo in tissue of virgin and pregnant rats. Diabetes 35:172-177

8. Pacold ST, Blackard WG 1979 Central nervous system insulin receptors in normal and diabetic rats. Endocrinology 105:1452-1457

9. Havrankova J, Roth J, Brownstein MJ 1979 Concentrations of insulin and of insulin receptors in the brain are independent of peripheral insulin levels. Studies of obese and streptozotocin treated rodents. J Clin Invest 64:636642

10. Frank HJL, Pardridge WM 1981 A direct in vitro demonstration of insulin binding to isolated brain microvessels. Diabetes 30:757-761

11. van Houten M, Posner BI 1979 Insulin binds to brain blood vessels in vivo. Nature 282:623-625

12. Ciaraldi T, Robbins R, Leidy JN, Thamm P, Berhanu P 1985 Insulin receptors on cultured hypothalamic cells: functional and structural differences from receptors on peripheral target cells. Endocrinology 116:2179-2185

13. Havrankova J, Roth J 1978 Insulin receptors are widely distributed in the central nervous system of the rat. Nature 272:827-829

14. Havrankova J, Sehmechel D, Roth J, Brownstein M 1978 Identification of insulin in rat brain. Proc Natl Acad Sci USA 75:5737-5741

15. Rhoads DE, DiRocco RJ, Osburn LD, Peterson NA, Raghupathy E 1984 Stimulation of synaptosomal uptake of neurotransmitter amino acids by insulin: possible role of insulin as a neuromodulator. Biochem Biophys Res Commun 1198-1204

16. Clark DW, Boyd FT Jr, Kappy MS, Raizada MK 1975 Insulin stimulates macromolecular synthesis in culture glial cells from rat brain. Am J Physiol 249:C484-C489

17. Yang JW, Fellows RE 1980 Characterization of insulin stimulation of the incorporation of radioactive precursors into macromolecules in cultured rat brain cells. Endocrinology 107:1717-1724

18. van Houten M, Posner BI, Kopriwa BM, Brawer JR 1978 Insulin-binding sites in the rat brain: in vivo localization to the circumventricular organs by quantitative radioautography. Endocrinology 105:666-673

19. Cornford EM, Braun LD, Olendorf W 1982 Developmental modulations of blood-brain barrier permeability as an indicator of changing nutritional requirements in the brain. Pediatr Res 16:324-328

20. Kliegman RM, Miettinen EL, Rolin WM, Adam PAJ 1981 Fetal and neonatal cerebral metabolism following maternal canine starvation. Pediatr Res 15:859-865

21. DeFronzo RA, Tobin JYD, Andres R 1979 Glucose clamp technique: a method for quantifying insulin secretion and resistance. Am J Physiol 237:E214E223

22. Sokoloff L, Reivich M, Kennedy C, Des Rosiers MH, Patlak CS, Pettigrew $\mathrm{KD}$, Sakurada O, Shinohara M 1977 The $\left[{ }^{14} \mathrm{C}\right]$ deoxyglucose method for the measurement of local cerebral glucose utilization: theory procedure and normal values in conscious and anthesthetized albino rat. $J$ Neurochem 28:897-916

23. James DE, Burleigh KM, Kraegen EW 1986 In vivo glucose metabolism in individual tissues of the rat. J Biol Chem 261:6366-6374

24. Margolis RV, Altszuler N 1967 Insulin in the cerebrospinal fluid. Nature 
215:1375-1376

25. Namba H, Lucignani G, Nehlig A, Patlak C, Pettigrew K, Kennedy C, Sokoloff L 1987 Effects of insulin on hexose transport across blood-brain barrier in normoglycemia. Am J Physiol 252:E299-E303

26. Hulman S, Kliegman RM, Heng J, Crouser E and Huang M 1986 Assessment of insulin resistance in newborn beagles with the euglycemic hyperinsulinemic clamp. Pediatr Res 20:189A(abstr)

27. Terrettaz J, Assimacopoulos-Jeannet F, Jean Renaud B 1986 Inhibition of hepatic glucose production by insulin in vivo in rats: contribution of glycolysis. Am J Physiol 250:E346-E351

28. Hernandez MJ, Vanucci RC, Salcedo A, Brennan RW 1980 Cerebral blood flow and metabolism during hypoglycemia in newborn dogs. J Neurochem 35:622-626

29. Kliegman R, Trindade C, Huang M, Hulman S Attenuated response to graded hyperinsulinemia in liver and muscle of the canine pup. Pediatr Res (in press) 